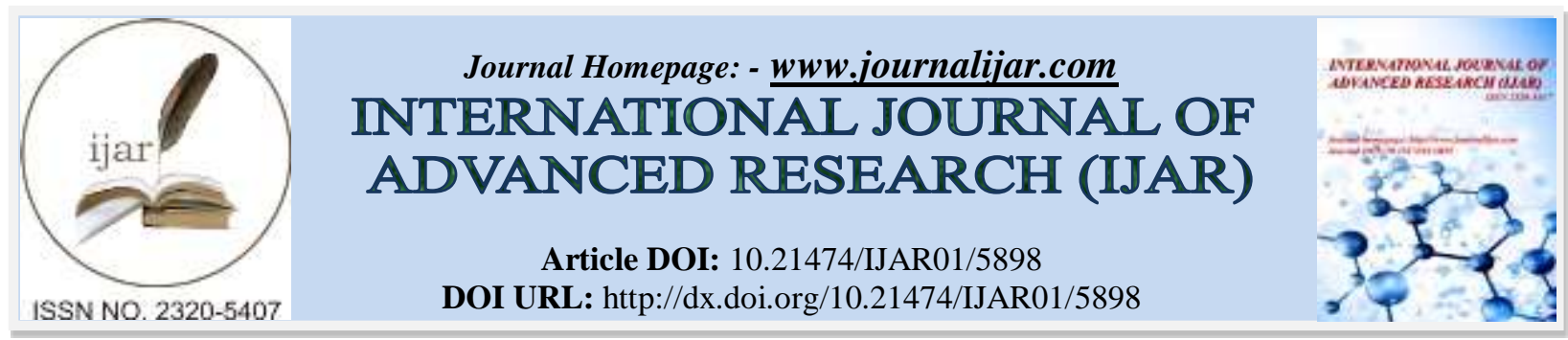

RESEARCH ARTICLE

\title{
EFFECT OF BURNING-FUEL EMISSIONS FROM AUTOMOBILES ON ATMOSPHERIC AIR AROUND ARABLE SOILS IN GOMBE LOCAL GOVERNMENT AREA, GOMBE STATE-NIGERIA.
}

\author{
Babangida Hammani ${ }^{1}$, Fatima Algunaid Hassan ${ }^{2}$ and Umar Ibrahim ${ }^{3}$. \\ 1. Department of Agricultural Education.Federal College of Education (Technical) P.M.B. 60 Gombe, Gombe \\ State, Nigeria. \\ 2. Department of Forestry and Range Science, University of Bakht Er-ruda, Ed-douiem, Sudan \\ 3. Department of Biology Education. Federal College of Education (Tech.) P.M.B. 60, Gombe. Gombe State, Nigeria.
}

\section{Manuscript Info}

\section{Manuscript History}

Received: 17 September 2017

Final Accepted: 19 October 2017

Published: November 2017

Key words:-

Arable soil; Automobiles emissions;

Carbon monoxide; Nitrogen dioxide;

Pollution; Sulfur dioxide.

\begin{abstract}
The study determine the level of Carbon monoxide, Nitrogen dioxide and sulfur dioxide emitted by automobiles as it affects arable soils in Gombe local government Area in Gombe state- Nigeria. Data were collected through the use of crown gasman detection machine for the period of 30days from April, 18-17 $7^{\text {th }}$ May, 2016. An average of monthly concentration reading of 1080 samples was taken from the selected arable soils within the local government. Data recording was made in the morning, afternoon and evening for all period of 30 days. The result reveal that average monthly concentration of burning fuels emitted over the arable soils exceeded the minimum of permissible limited set by federal ministry of environment. It was recommended that air pollution monitory station should be established to regulate air pollution in the study area.

Copy Right, IJAR, 2017,. All rights reserved.
\end{abstract}

\section{Introduction:-}

Introduction of fuel consuming vehicles and the explosion of human population are among the various factors contributing toward air pollution which plant and animals experienced (Babangida, 2010). Air pollution is an environmental problem in the third world countries. Nigeria is known to be among the most intensive atmospheric aerosols regions of the world with the two main pollutants sources as particles from the desert zones of Sahara, and biomass burning that produce huge amount of black and organic carbon that accounts for over $70 \%$ of air pollution in the country. The most notable gases that end as pollutants in the air are $\mathrm{NOX}, \mathrm{CO}$, and $\mathrm{SO}_{2}$ that comes from combustions in vehicles, domestic power generators and industrial activities. The resultant effect of the concentration of these gases with respect to human health, protection of natural resources and the socio-economic development of the country has become a challenge to science and technology (Federal Ministry of Environment Nigeria, 2015). Lagos Metropolitan Area Transport Authority (LAMATA) through its Lagos Air (vehicular emission) Quality Monitoring Study (LAQMS) reported that from 2007-2008 transport is a major source of air pollution in the city. While in the United Kingdom research has shown how exhaust pollution from diesel engines is able to affect nerves within the lung and identified potential mechanisms linking exposure to diesel exhaust and the exacerbation of respiratory diseases with the concentration of $\mathrm{NO}, \mathrm{SO} 2$ and $\mathrm{CO}$ exceeding the WHO guidelines at most location for in-situ measurement and 24-hour exposure. The mean concentration of NOx, SO2 and CO was found to be 31.5ppb, 28.6ppb and 11.9ppm respectively for 24-hour exposure. 
While developed nations adopt stringent air quality requirement to control air pollution from point and non point sources (Encyclopedia American International EPA, 2010), the situation is different in most developing countries including Nigeria where air pollution control is not given the necessary priority it deserves and therefore the consequences of this increased pollution of air eventually gets into human body and animals resulting in health related problems. The situation is compounded by the fact that most of these countries have their air quality deteriorated due to emission by automobiles and hazardous gases through manufacturing companies exuding harmful exhaust vapour. (Schwart, 2003)

The term air pollution is used to describe the introduction of substance artificially into the air that is harmful to human health, plant, animals and ecosystem. (Ahmed and Ayodele, 2004) defined air pollution as contamination of air by unwanted gasses, smoke particles and other substances. Nigerian Federal ministry of environment identified major causes of air pollution as: -increase in population density resulting in increase in transportation emissions/square kilometer, increase in the number of fairly used vehicles, increase in the number of house hold power generators, road traffic system, maintenance system, control measures in place, Weak legislation, and lack of effective enforcement.

\section{Problem Statement:-}

There is persistence demand for fuel to drive transportation vehicles in the study area as an emerging city in the North-eastern region which ends as exhaust fumes in the air. There is also an increased influx of people from different part of the country to the city due to its commercial potentials in the North-Eastern zone; this led to more and more number of generating machines as an alternative source of power. Consequently, there may be high emission of $\mathrm{CO}, \mathrm{SO}_{2}, \mathrm{NO}_{2}$ and other burnt fuel products into the air which affects environmental air quality and constitute hazard to human, animal and plants. Particulate Matter (PM), asbestos, Sulfur Dioxide (SO2), Nitrogen Oxide (NO), Carbon Monoxide (CO), and partially uncombusted hydrocarbons contribute to the death of seven million people - one in eight of total global deaths - as a result of air pollution exposure (Chinedum et.al., 2015). It is therefore the interest of the researcher to investigate the level of gases emitted around the arable soils areas within Gombe local government area.

\section{Objectives of the Study:-}

The main objectives of this study was to determine the gases emitted by automobile in selected arable land within Gombe local government area in Gombe state using Gasman defection machine. It has the following specific objectives.

1. To determine the level of burning fuel gases (carbon monoxide, Nitrogen dioxide, sulfur dioxide) in the air over the study area.

2. To compare the result obtained from selected areas with national and international standards.

\section{Research Questions:-}

1. What is the level of burning fuels (Carbon monoxide, Nitrogen dioxide, Sulfur dioxide) in the air over arable soils in Gombe Local Government Area?

2. What is the extent of burning fuel emissions in the area when compare with National and International standard.

\section{Area of Study:-}

The area of this research is Gombe metropolis, the administrative capital of Gombe State and double as 0-=Gombe local government area. The local government area is located within latitude $9^{0} 3^{\circ}$ and $12^{0} 3^{\circ} \mathrm{N}$ and longitude $8^{0} 45^{\circ} \mathrm{E}$ with a population of 1.88 million according to 1991 census. Gombe is located in Savannah region and has a land area of about $105,45 \mathrm{~km}^{2}$. The temperature has as high as of $42^{\circ} \mathrm{c}$ and its lowest of $26^{\circ} \mathrm{C}$. It has a fair terrain with streams and hills. Gombe is endowed with both human and natural resources, most of its inhabitants are commercially oriented as well as Agriculturalists. Gombe metropolis shares common boundary with Yamaltu/Deba to the east, Akko to the South and to the West, and Kwami Local Government area to the North.

\section{Materials and Method:-}

The research design was experimental study which targeted assessing the level of automobiles emission (Carbon monoxide, Nitrogen dioxide, and sulfur dioxide) in the atmosphere around arable soils areas in Gombe local government area. Four (4) sample areas were selected using purposive sampling. The sampled areas included Bauchi road arable area, Dukku road arable land, Biu road arable land and Kumo road arable soils. The instrument used for 
data collection was crown gasman machine. A total of 1,080 recordings were conducted within a period of 30days in dry season. Three (3) field assistants helped in the data collection and were positioned at the identified four sample collection areas to take readings of the burning-fuels gases three (3) times daily, in the morning 7:00am-8:30pm, afternoon 12:00-1:30pm and evening 4:30pm-6:00pm. During the period of data collection gasman "FL" and gasman "TO" were used. The 'FL' is designed to monitor the presence of particular harmful gasses. Sample of carbon monoxide, nitrogen dioxide and sulfur dioxide were observed. Operation of the instrument was by placing in normal air, the switch was turned to the gas position, the green led and the sounder operated once in every three seconds to obtain normal operation. The displayed reading was ensured to be zero. The crown gasman sensor used a catalytic bead which confirms analysis in descriptive statistics.

\section{Result and Discussion:-}

Table 1 revealed the average monthly carbon monoxide concentration of four different livestock fattening areas of about 7565.6 mean value which is very high when compare with Standard by federal ministry of environment (FME) which is $25.574 \mathrm{ppm}$

Table 1:- Carbon Monoxide Concentration (ppm)

\begin{tabular}{|l|c|c|c|c|c|}
\hline Items & Bauch Road & Dukku Road & Biu Road & Kumo Road & mean \\
\hline Morning & 5115.0 & 7672.1 & 7672.1 & 7672.1 & 7032.8 \\
\hline Afternoon & 3836.0 & 5115.0 & 5115.0 & 5114.7 & 4795.2 \\
\hline Evening & 12786.8 & 11508.1 & 11508.1 & 7672.1 & 10868.8 \\
\hline Average & 7245.9 & 8097.7 & 8098.4 & 6819.6 & 7565.6 \\
\hline
\end{tabular}

Table 2 revealed the monthly mean value for the concentration of Nitrogen dioxide within the four (4) different livestock fattening areas of about 193.6 which is higher than standard of 51.1 or 63.9 by the Federal Ministry of environment.

Table 2:- Nitrogen dioxide concentration (ppm)

\begin{tabular}{|l|l|l|l|l|l|}
\hline Items & Bauch Road & Dukku Road & Biu Road & Kumo Road & mean \\
\hline Morning & 127.8 & 127.8 & 383.6 & 127.8 & 191.7 \\
\hline Afternoon & 255.7 & 255.7 & 255.7 & 127.8 & 223.7 \\
\hline Evening & 127.8 & 00.0 & 255.7 & 277.7 & 165.3 \\
\hline average & 170.4 & 127.8 & 298.3 & 177.8 & 193.6 \\
\hline
\end{tabular}

Standard:- 0.04-51.1, 0.05-63.9

Table 3 revealed that mean value for the concentration of Sulfur dioxide within the four different arable soils areas in Gombe local government was 85.2 which is lower than standard of 127.8 by the Federal Ministry of Environment.

Table 3:- Sulfur dioxide concentration (ppm)

\begin{tabular}{|l|l|l|l|l|l|}
\hline Items & Bauch Road & Dukku Road & Biu Road & Kumo Road & mean \\
\hline Morning & 127.8 & 127.8 & 127.8 & 127.8 & 127.8 \\
\hline Afternoon & 00.0 & 00.0 & 127.8 & 127.8 & 63.9 \\
\hline Evening & 00.0 & 00.0 & 255.7 & 277.7 & 165.3 \\
\hline average & 42.6 & 42.6 & 127.8 & 127.8 & 85.2 \\
\hline
\end{tabular}

Standard by FME $=127.8$

\section{Conclusion:-}

The result from this study revealed that the average monthly concentration level of burning fuels, especially CO and $\mathrm{NO}_{2}$, emitted around arable areas in Gombe have exceeded the maximum permissible limit set by Federal Ministry of Environment. The resultant effect is increasing the level of pollutants in the air and having deleterious effects on crops in the area.

\section{Recommendations:-}

Based on the results, the following recommendations were suggested

1. Air pollutant monitoring station should be establish by the ministry of environment at strategic locations to regulate air pollutions 
2. Government should enact laws on banning aged vehicles used for transportation in the state as they constitute substantial volume of exhaust fumes

3. Green zones, recreational gardens and conservation plantations should be built so as to help in purifying the air by absorbing pollutants. These should be well maintained and protected against encroachment.

4. State ministry of environment should ensure compliance with existing regulations and standard on vehicles emission as a long term measure.

\section{References:-}

1. Ahmed, A. and J.T. Ayodele (2004) Monitoring air pollution in Kano earth and environment science. Springer Netherlands. Vol. 21 No. page 145-1551

2. Albert, W. (1992), The Increase in the emission of pollutants and their effects, the New Politics of Pollution Manchester, Manchester Cambridge University Press. Journal.cambridge.org

3. Austin, C. (1998) Bicycling and our environment. News

4. Breuer, G. (1980), "Air in Danger". Ecologico Perspective of the Atmosphere New York. Cambridge University Press.

5. Carter, F.N and Turnock, D. (1993) Environment Problem in Eastern Europe (route Ledge).

6. Council on Environmental Quality, Pengum (1982). The Global 200 report to the President entering the $21^{\text {st }}$ Century

7. Smag, (1978). Maintaining the qualitative natural air in the city "Managing Urban AirQuality' Earth canPublication Limited. 1-12.

8. Dorfman, R. and Dorfman, N.S (1993). Economics of the Environment Selected reading $3{ }^{\text {rd }}$ Norton.

9. Derek, E (2014) "Smog Alert”: Managing Urban Air Quality. Routledge Publishers. Book

10. EPA.(2010) National Vehicle and Fuel Emission Laboratory.2565 Plymouth Ann Arbor.

11. Francis, B.H (1994) Toxic Substance in the Environment Wiley.

12. Goespa, (2004).Gombe State Environment Protection Agency Law Enacted in 2004.

13. Herman K. (1991), "Air Pollution Injury to vegetation" National Air Pollution Admin Ap-71 Releigh, N.C.

14. Horward S.P, Donalad, R. George T. (1985) "Environment Engineering” $\quad$ MC Graw Hill, Inc 41440.

15. Jane, A.G., (2003). The history of improving automobile emission.Chemical educator, vol. 8 No. 6 published university Malibu press

16. Juke, S.B. and Hall, L. (1986) The Environmental Crisis Opposing View Points St. Paul, MN Green Haven Press pg216.

17. Lodha, R.M (2007) Academic Geography Dictionary. ${ }^{\text {st }}$ Edition page 11.

18. Michael B. (1998). Bicycling in austin. Hov Lanes.

19. Miller, G.T (1990). Living in the Environment an Introduction to Environmental screnced Beimonth. Wadsworth.

20. Nesrea, (2007), National Environmental Standard and Regulatory Enforcement Agency establishment Act 2007. Federal Republic of Nigeria.

21. Olofin, E.A (1993) The effect of environmental degradation on food and population. London Macmillan publishing Itd.

22. Oluyole, F. (2010). Managing the Air Quality in Nigerian Cities. Retrieve on 14/05/2010

23. Ronald, N.E. (1995). Fate and Transport of Organic Chemicals in the Environment $2^{\text {nd }}$ edition Government Institute.

24. Edwin, M., Rosen, E.D., (1971), The Paterson Automotive Troubleshooting and Repair Manual, Published at Grosset and Dunlop Inc. Book.

25. Federal Ministry of Environment Nigeria. (2015). Fuel Quality Progress In Nigeria For Nigeria National Air Quality Management Program. Accessed on 14/01/2017 at http://www.unep.org/transport/new/pcfv/pdf/2015_Ecowas_FuelQualityProgress_Emmanuel.pdf

26. Scwartz, J. (2003). No Way Back, Why Air Pollution will continue to Decline. AEI Press, Washington, D.C.

27. Dan'azumi, S. and M.H. Bichi. (2009) Industrial Pollution and Heavy Metalsprofiles of Challawa River in Kano, Nigeria.Journal of Applied Science in Environmental Sanitation. 1; 56-62

28. Stewart, T.C. (1979). Air Pollution and Policy, Lexington Book, Air 148 pages review edition.

29. Sullivan, T.F.P. (1984) United States Environmental Protection Agency Guide Book USGP.

30. Sunyer, J. (2001). Urban Air Pollution and Chronic Obstructive Pulmonary Diseases A. Review" European Respiratory Journal 17 (5): 1024-1033 Doi:10.1183/0903193601. 
31. Tillman, D.A (1994) Trace Metal in combustion System.Academic Press. San Diego. U.S. Environmental Protection Agency (1994). Automobile Emission, Fact Sheet QMS-5 An Overview Cars and Pollution.Emission from Individual Car.

32. U.S. Environmental Protection Agency (2010) Exhaust Emissions Regulation Cummins Engine: Heavy Duty on Highway Diesel Engines tobe introduced.

33. Wark, K. and Cecil F.W. (1981). Air Pollution its Origin and Control $2^{\text {nd }}$ Edition Harper.

34. Whittow, J.B. (2000). Physical Geography Dictionary. $2^{\text {nd }}$ Edition page 407.

35. Chinedum, U., Tunde, A., and Chukwuma, M. (2015). Pollution Threatens Air Quality. Accessed on 14/01/2017 at http://guardian.ng/news/pollution-threatens-air-quality/ 